\title{
Relationship Strategy Coping with Self-Efficacy Drugs in the Period of Rehabilitation at Batam BNN Rehabilitation
}

\author{
Rachmawaty M Noer ${ }^{1}$, Laily Fitriana ${ }^{2}$, Mira Agusthia ${ }^{3}$ \\ 1,2,3 Nursing, STIKes Awal Bros Batam, Indonesia \\ $\underline{{ }^{1} \text { Rachmawatymnoer1977@gmail.com, }{ }^{2} \text { lailyf16@gmail.com, }{ }^{3} \text { agusthiamira@gmail.com }}$
}

\begin{abstract}
\section{Keywords:}

Coping Strategy;

Self-Efficacy;

Drug;

Rehabilitation.

In 2017 , there were 26,540 drug users in Riau Islands. 3 out of 10 people who undergo rehabilitation has experienced relapse. If drug users can use coping strategies effectively, self-efficacy or confidence can develop well. The implication is that drug users can control themselves so as not to relapse. The purpose of this study was to examine the relationship between coping strategies and self-efficacy of drug users during rehabilitation. This research is correlational research. The instruments used in this study were the coping scale and self-efficacy. These instruments were used after being tested and declared as valid and reliable. The sample in this study were 35 people who were undergoing a program in the primary program and reentry program at the Rehabilitation Workshop in BNN Batam which taken by cluster random sampling technique. The findings of this study are (1) the majority of the coping strategies of respondents are at a moderate level with a percentage of $88.57 \%$; (2) the majority of respondents have high level self-efficacy with a percentage of $80 \%$; and (3) there is a relationship between coping strategies and drug users' self-efficacy during the rehabilitation period with $\mathrm{p}$ value 0,011 . It is expected that drug rehabilitation institutions can increase the level of coping strategies and self-efficacy of drug users in the rehabilitation period by teaching the coping skills and relapse prevention as well as exploring sources of selfefficacy.
\end{abstract}

Article History:

Received: $17-10-2019$

Revised : 24-11-2019

Accepted: 29-12-2019

Online : $30-12-2019$

\author{
(c) (1) (2) \\ This is an open access article under the CC-BY-SA license \\ Crossret \\ https://doi.org/10.31764/ijeca.v2i3.2099
}

\section{A. INTRODUCTION}

In the province of Riau Isles, the number of persons to reach 26,540 people from the population is $10-59$ years of $1,556,300$, or reaching $1.71 \%$ of its prevalence. The amount is very concern, meaning that in about 60 people there are 1 people who abuse NAPZA. The high prevalence of those who use NAPZA poses many problems for both users and others. So the government seeks to reduce the prevalence rate through rehabilitation (Badan Narkotika Nasional Republik Indonesia, 2019). In Law No. 35 year 2009 on narcotics, it is explained that NAPZA addicts and NAPZA abuse victims are obliged to follow both medical and social rehabilitation. And explained in the regulation of BNN RI No 24 years 2017 that rehabilitation is an integrated effort done to DRUG addicts, abusers NAPZA and victims of NAPZA abuse, which includes the admission process, medical rehabilitation, social and pascarehabilitation. In fact, 
rehabilitation is not easy because NAPZA addicts can repeat their deeds by returning to consume NAPZA (Relapse). (Suisno, 2017)

In achieving the restoration in undergoing a series of such rehabilitation processes, selfefficacy is considered important. This is because self-efficacy can reflect the level of individual belief in maintaining the behavior to face the situation that often triggers for relapse (Priyoto, 2014). According to Fauziannisa, if the misuse will can resurrect self-efficacy on himself effectively at the time of recovery then the misuse will is able to control himself to remain recovered and not re-use NAPZA or can be said relapse, and he can also commit to himself to remain rehabilitation at the Rehabilitation Institute. (Fauziannisa, 2013)

When individuals get stressor or pressure from outside, the individual has a coping with strategy as a defence of him. The coping with strategy aims to deal with the circumstances, the pressures that can overload, and exceed the resources it possesses. The coping with resources of the possession will affect the coping with strategy that will be done in resolving various problems (Maryam, 2017). Meanwhile, coping with is interpreted as an individual process to try to manage the distances between demands for both the demands of the self and from the environment of the ability possessed in the face of a pressing situation (Rahmawati, 2016).

In theory, a coping with strategy that is owned by a person can affect self-efficacy on him. When one can use the strategy of coping with effectively, the self-efficacay or beliefs that it has can be good, but also the opposite if the coping with strategy used is ineffective, then the selfefficacy that is also will be low or not good (Pridmore \& May, 2018).

According to the daughter's research, there is a strong and significant relationship between self-efficacy and the relapse tendencies (re-using NAPZA), the more a person has a high selfefficacy then the lower the tendency of addicts to relapse, and vice versa. It also research results from Yunitasari obtained the result that the stronger self-efficacy level owned by the presenter then the stronger the efforts of the relapse prevention is done. Based on preliminary studies conducted by the authors, obtained data from the information psychologist at the BNN rehabilitation area of Batam around $70 \%$ of the resident is unaware of the mistake, they blame the external factor as the cause of their use of NAPZA. (Yunitasari, 2018)

In addition, the data obtained more than $50 \%$ of the number of residents undergoing rehabilitation program is still in the lowest change stage of pre contemplation or can be said the client has a low desire or motivation to recover. The assessment was done 2 times, at the beginning and end of the rehabilitation program. From the research that has been done by the Batam BNN Rehabilitation Workshop, obtained data that from 10 resident who underwent rehabilitation at BNN Rehabilitation workshop in Batam 3 including relapse.

\section{B. METHODS}

This research is a correlation study to know the relationship of coping with strategy with self-efficacy the Penyalah for NAPZA during rehabilitation period. The study used a random sampling cluster technique with an instrument of scale coping with strategies developed by Lazarus and Folkman (Lazarus, 1991) and adopted by Atmawijaya (Atmawijaya, 2018), as well as the self-efficacy scale developed by Supriyanto and Hendiani (Supriyanto \& Hendiani, 2018). The scale of the coping with strategy and the scale of the self-efficacy has been tested against 30 resident at the BNN Rehabilitation workshop in Batam and declared valid and reliable, acquired self-efficacy scale reliability coefficient is 0886 and the reliability coefficient at a scale of coping with strategy of 0,927 . The Instrument is measured on a likert scale, with low, medium and high measuring results. This research was conducted against 35 respondents who were undergoing a program at the primary program and re-entry program at the BNN Rehabilitation workshop in Batam, located at Jl. Hang Jebat, KM. 3, BatuBesar, Nongsa, Batam. The analysis of data performed is a non-parametric statistic with a grammar correlation test (Spearman). In this study the hypothesis tested was as follows: 
H0: No relationship strategy coping with with self-efficacy for NAPZA use at the time of rehabilitation at the BNN Rehabilitation Workshop

H1: There is a strategic relationship coping with with self-efficacy misuse will for napza at the time of rehabilitation at the BNN Rehabilitation Workshop.

\section{RESULT AND DISCUSSION}

From the results of the research at the Batam BNN Rehabilitation Workshop to study the relationship strategy coping with with self-efficacy obtained data that P-value of 0.011 and the coefficient of the correlate 0.424 , meaning there is a relationship in moderate level.

Table 1. Frequency distribution of respondents characteristics at BNN Rehabilitation Workshop

\begin{tabular}{|c|c|c|c|}
\hline No & Respondents Characteristics & f & $\%$ \\
\hline \multirow[t]{6}{*}{1} & Age & & \\
\hline & a. $<20$ & 8 & 22,86 \\
\hline & b. 20-30 Years & 19 & 54,29 \\
\hline & c. $30-40$ Years & 7 & 20 \\
\hline & d. $>40$ Years & 1 & 2,86 \\
\hline & Total & 35 & 100 \\
\hline \multirow[t]{4}{*}{2} & Sex & & \\
\hline & a. Male & 34 & 97,14 \\
\hline & b. Female & 1 & 2,86 \\
\hline & Total & 35 & 100 \\
\hline \multirow[t]{7}{*}{3} & Education & & \\
\hline & a. SD & 3 & 8,57 \\
\hline & b. SMP & 7 & 20 \\
\hline & c. SMA & 23 & 65,71 \\
\hline & d. D3 & 1 & 2,86 \\
\hline & e. S1 & 1 & 2,86 \\
\hline & Total & 35 & 100 \\
\hline \multirow[t]{5}{*}{4} & Time of Reghabilitation & & \\
\hline & a. 2 Months & 2 & 5,71 \\
\hline & b. 4 Months & 15 & 42,86 \\
\hline & c. 6 Months & 18 & 51,43 \\
\hline & Total & 35 & 100 \\
\hline
\end{tabular}

Based on Table 1, it can be concluded that the respondents ' age in the study was largely at the age range of $20-30$ years, which is $54.29 \%$. The male majority sex is $97.14 \%$. Whereas if seen from the education of respondents most have a high school education of $65.71 \%$. The duration of the majority rehabilitation for 6 months is $51.43 \%$.

From the results of the research using measuring instruments of the scale of coping with strategy to 35 respondents who are at the primary and re-entry program, obtained the following data:

Table 2. Frequency distribution Strategy Coping

\begin{tabular}{ccc}
\hline Categori & Frequency & Persentage (\%) \\
\hline Hight & 3 & 2,86 \\
Medium & 31 & 88,57 \\
Low & 1 & 8,57 \\
Total & $\mathbf{3 5}$ & $\mathbf{1 0 0 \%}$ \\
\hline
\end{tabular}

Based on Table 2 above, shows that the coping with strategy used by the resident at the time of rehabilitation in the BNN rehabilitation area of Batam is mostly at a moderate level of $88.57 \%$. 
Table 3. Self-Efficacy Frequency distribution

\begin{tabular}{ccc}
\hline Categori & Frequency & Persentage (\%) \\
\hline Hight & 28 & 80 \\
Medium & 7 & 20 \\
Low & 0 & 0 \\
Total & $\mathbf{3 5}$ & $\mathbf{1 0 0 \%}$ \\
\hline
\end{tabular}

According to Table 3 above, shows that self-efficacy owned by resident at the time of rehabilitation at the BNN Rehabilitation District of Batam is mostly at a high level of $80 \%$ or as many as 28 people, while 7 others are on a moderate level.

Table 4. Coping strategy relationship with Self-Efficacy in the Penyalah for NAPZA at the time of

\begin{tabular}{|c|c|c|c|c|c|c|}
\hline \multirow{3}{*}{$\begin{array}{c}\text { Coping } \\
\text { Value } \\
\text { Strategy }\end{array}$} & \multicolumn{4}{|c|}{ Self-Efficacy } & \multirow{3}{*}{ Total } & \multirow{3}{*}{ Value } \\
\hline & \multicolumn{2}{|c|}{ Medium } & \multicolumn{2}{|c|}{ Hight } & & \\
\hline & $\mathrm{f}$ & $\%$ & $\mathrm{f}$ & $\%$ & & \\
\hline Low & 1 & 2,85 & 0 & 0 & 1 & \\
\hline Medium & 5 & 14,3 & 26 & 74,3 & 31 & 0,011 \\
\hline Hight & 1 & 2,85 & 2 & 5,7 & 3 & \\
\hline Total & 7 & 20 & 28 & 80 & 35 & \\
\hline
\end{tabular}

From the Table 4 above, you get the data that the resident in Batam BNN rehabilitation workshop mostly have a moderate level coping with strategy with a self-efficacy high of 26 people or $74.3 \%$, then some have a moderate coping with strategy with a self-efficacy being as much as 5 people or by $14.3 \%$. In addition there are 2 people or $5.7 \%$ who have a strategy coping with with high self-efficacy, in addition there is 1 person or $2.85 \%$ who have a low coping with strategy with self-efficacy moderate and high coping with strategy with a self-efficacy medium.

From the test result of the level of governance (Spearman rank) obtained data that the strategy coping with with self-efficacy has a significant relationship $\mathrm{p}<0.05$ P-Value of 0.011 . Thus the $\mathrm{H} 1$ hypothesis is accepted that there is a link between the coping with strategy with self-efficacy in the case of DRUGS for NAPZA at the time of rehabilitation at the Batam BNN Rehabilitation Workshop. The value of by correlation of this research of 0.424 , this research has a relationship at a moderate level, with a by determination of R2 0.18 means coping with strategy contributes by $18 \%$ affects self-efficacy.

Based on a descriptive statistical analysis, the results of the average respondent had a coping with strategy score of $61.71(55.6 \%)$ Or at a moderate level. With the highest score is 79 $(71.17 \%)$ Or at a high level. While respondents with the lowest coping with strategy were at a low level with a score of 36 (32.43\%).

Whether reviewed from the average or majority percentage, the strategy of coping with respondents to the DRUG for NAPZA at the Batam workshop is at a moderate level. Fauziannisa mentions that respondents with a strategy of coping with at a level are being interpreted that the suppress NAPZA at the time of recovery can resolve the demands that occur, both internal and external only at moderate intensity. Therefore, the results of the analysis indicate that the majority of the respondents to the DRUG for NAPZA in the Batam rehabilitation workshop at the time of its recovery can resolve the demands that occur, both internal and external only at moderate intensity. (Fauziannisa, 2013)

Furthermore, when the coping with strategy is seen in more depth, the resident in the face of the demands/stressor can use a coping with strategy focusing on coping with issues or 
strategies focused on emotions, and can also use both simultaneously. Focused's coping with strategy of the problem will be more likely to focus on how to resolve the problem directly, solving the problem can focus on problems in the environment or more focused on the problem in itself. While the coping with strategy focuses on emotions it is a problem solving to reduce or regulate the emotional stress that occurs when interacting with the environment.

Self-efficacy is defined as a person's self-assessment of the belief to be able to plan and implement action to achieve certain successes (Priyoto, 2014). Therefore, self-efficacy can be interpreted as a person's self-assessment with regard to its ability to succeed in the face of problems that occur.

In this study, self-efficacy related to self-assessment or resident confidence in its ability to achieve success in rejections and overcoming obstacles to abandon NAPZA. The self-assessment is also related to resident self-confidence to avoid the reuse of NAPZA which can lead to relapse.

Based on the results of the study, obtained the findings that the majority of DRUG respondents to NAPZA in Batam Workshop is at a high level of $80 \%$, while the remaining $20 \%$ are on a moderate level. Further, based on the statistic descriptive analysis results, the average respondent gained a score of $82.66(75.15 \%)$ or high level on self-efficacy. The highest selfefficacy score of respondents was 99 (90\%) Or reach a high level. Meanwhile, the respondent's lowest score was $64(58.18 \%)$ or reaching moderate levels.

Based on these results, both from the percentage of majority and on average, self-efficacy respondent for NAPZA is at a high level. This indicates that the respondent has a self-assessment or high conviction to not re-consume NAPZA and avoid NAPZA.

From the results of the research conducted at BNN in Rehabilitation Museum obtained the findings that 28 people from a total of 35 people have a high self-efficacy, based on the analysis and the explanation of the Sebecan be interpreted that the respondents have a low tendency to be able to relapse.

Self-efficacy are influenced by several factors, among others: experience of success, experience of others ' success, social persuasion as well as physiological and emotional state. Of these factors, the success experience is one of the main factors that affect the self-efficacy of a person. The more often a person succeeds in solving the problem, the higher the self-efficacynya will be. The experience of success in resolving problems is also related to coping strategies. In addition, other factors that also affect self-efficacy are seeing the experience of others successfully undergoing rehabilitation and can recover, support from the family, support counselors, support friends, motivation spirit to recover and immediately re-gathered with family and can function socially well.

Research results related to the relationship strategy coping with with self-efficacy misuse will for napza at the time of rehabilitation at the BNN Rehabilitation Workshop by using the correlation analysis Spearman rank obtained the P-value of 0.011 , which is less than $\alpha=0.05$ with a correlation coefficient of 0.424 , so that the work hypothesis (H1) is accepted and shows there is a significant relationship between coping with strategies with self-efficacy misuse will for napza during rehabilitation at the BNN Rehabilitation Workshop. The correlation with the score 0.424 shows the degree of relationship strength between the two variables being in moderate level.

There are four sources that affect the self-efficacy of a person according to Priyoto (Priyoto, 2014) among others: experience of success, experience of the success/failure of others, social persuasion, and the physiological and emotional state of a person. Success experiences For example he once succeeded in stopping and leaving NAPZA in his own effort. Other people's 
experiences such as seeing other people's experiences have undergone rehabilitation and can recover. Social Persuasion For example respondents have support from the family, support counselors, support friends. Meanwhile, physiological and emotional conditions for example are related to motivation, spirit to recover high and immediately again gathered with family and can function socially well. Self-efficacy in a person affects the efforts, ways, and actions taken and their persistence in the face of obstacles. Self-efficacy one can be classified over self-efficacy high, self-efficacy medium and low self-efficacy.

The higher the self-efficacy level that the resident will be the lower the resident's tendency will re-use NAPZA after leaving the Rehabilitation Institute. This is strengthened by the results of the Study of Women which found that there is a strong and significant relationship between self-efficacy and the relapse tendencies, where the higher the self-efficacy a person will lower the chances of the likelihood of relapse tendencies, but rather the lower self-efficacy one will be the higher the chances of the person for relapse.

From the results of the study conducted 28 of 35 people (80\%) is at a high self-efficacy level while only 7 people are on the self-efficacy level. So that it can be indicated that the resident who is undergoing rehabilitation at the BNN workshop, Batam will almost completely recover and not relapse. It is supported by Fauziannisa (Fauziannisa, 2013) stating that in the context of the abuse of NAPZA, a person who is in the restoration if able to awaken self-efficacy on himself effectively, then he can regulate himself from the desire to reuse illegal drugs, have a definite purpose to recover and no longer abuse NAPZA. Therefore, the strategy of coping with becomes an important element for the abuse of NAPZA that is being rehabilitated in the framework of healing and recovery from DRUGS. The coping with strategy used effectively can develop selfefficacy for the better. Therefore, the presence of relationship strategy coping with and selfefficacy support and reinforce the statement that if one can conduct coping with strategies effectively, the person can have a good self-efficacy.

Based on the research results gained a correlation coefficient of coping with strategy relationship with self-efficacy of 0.424 . Can be obtained the value of coefficient of determination of R2 of 0.18 , meaning that coping with strategy contributes $18 \%$ to self-efficacy, while $82 \%$ is contributed by other factors. These other factors can be associated with other variables of the self-efficacy that are not examined in this study.

\section{CONCLUSION AND SUGGESTIONS}

Based on the research that researchers have done to 35 respondents about Coping strategy relationship with Self-Efficacy Penyalahguna NAPZA at BNN Rehabilitation Workshop in Batam year 2019 , the conclusion that as many as 31 people (88.57\%) has a coping with strategy at a moderate level, as many as 28 people (80\%) has self-efficacy at a high level and there is a relationship with the moderate level between coping with strategy with self-efficacy misuse will for napza during rehabilitation at BNN Rehabilitation Workshop in Batam year 2019 with the value $\mathrm{P}=0.011$ where $(\mathrm{p}=<0.05)$ and obtained the value of the correlation coefficient of 0.424 .

\section{ACKNOWLEDGEMENT}

A thank you researchers say to the lecturers STIKesAwal Bros Batam who have guided and gave directions so that the research can be carried out well and the party to the BNN Rehabilitation workshop that has given permission to conduct research on the resident who is undergoing rehabilitation. 


\section{REFERENCES}

Atmawijaya, I. G. A. R. (2018). Pengaruh strategi coping terhadap stress pada perempuan bali yang menjalani triple roles di instansi militer denpasar.

Badan Narkotika Nasional Republik Indonesia. (2019). Indonesia Drugs Report 2019. In Pusat Penelitian dan Informasi Badan Narkotika Nasional Republik Indonesia (Puslidatin BNN). https://doi.org/10.1017/CB09781107415324.004

Fauziannisa, M. (2013). Hubungan antara Strategi Coping dengan Self-efficacy pada Penyalahguna Narkoba pada Masa Pemulihan. Jurnal Psikologi Kepribadian Dan Sosial, 02(03), 136-140.

Lazarus, R. S. (1991). 8: Folkman, S.(1984). Stress, appraisal, and coping. New Yoyk: Springer.(ラザルス, R. https://doi.org/10.1016/0014-2921(91)90017-D

Maryam, S. (2017). Strategi Coping: Teori Dan Sumberdayanya. JURKAM: Jurnal Konseling Andi Matappa, 1(2), 101. https://doi.org/10.31100/jurkam.v1i2.12

Pridmore, S., \& May, T. (2018). Relapse prevention (RP) TMS. Brain Stimulation, Vol. 11, pp. 1391-1392. https://doi.org/10.1016/j.brs.2018.08.004

Priyoto. (2014). Teori Sikap dan Perilaku dalam Kesehatan (Dilengkapi Contoh Kuesioner). Yogyakarta: Nuha Medika.

Rahmawati, F. (2016). Proceeding of Chemistry Conferences vol.1(1) 2016: 10th Joint Conference on Chemistry. Proceeding of Chemistry Conferences, 1(1). https://doi.org/10.20961/pcc.v1i1.1394

Suisno, S. (2017). Tinjauan Yuridis Perantara Tindak Pidana Narkotika Menurut Undang-Undang Nomor 35 Tahun 2009. Jurnal Independent, 5(2), 69. https://doi.org/10.30736/ji.v5i2.75

Supriyanto, A., \& Hendiani, N. (2018). Self-efficacy level to recover from addiction in substance users in the center for Drug Rehabilitation. Counsellia: Jurnal Bimbingan Dan Konseling, 8(2), 114. https://doi.org/10.25273/counsellia.v8i2.2944

Yunitasari, I. (2018). Hubungan Dukungan Keluarga dan Self-Efficacy dengan Upaya Pencegahan Relapse pada Residen Penyalahguna NAPZA Pasca Rehabilitasi di Badan Narkotika Nasional Provinsi Kalimantan Timur. PSIKOBORNEO Jurnal Ilmiah Psikologi, 6(2). Retrieved from http://ejournal.psikologi.fisip-unmul.ac.id/site/?p=1874 